\title{
Mycosis Fungoides and Sezary Syndrome T1 TNM Finding v8
}

National Cancer Institute

\section{Source}

National Cancer Institute. Mycosis Fungoides and Sezary Syndrome T1 TNM Finding v8. NCl Thesaurus. Code C141331.

Limited patches, papules, and/or plaques covering less than $10 \%$ of the skin surface. Note: for skin, patch indicates any size skin lesion without significant elevation or induration. Presence/absence of hypo- or hyperpigmentation, scale, crusting, and/or poikiloderma should be noted. Plaque indicates any size skin lesion that is elevated or indurated. Presence or absence of scale, crusting, and/or poikiloderma should be noted. Histologic features such as folliculotropism, large-cell transformation (more than 25\% large cells), and CD30 positivity or neg ativity, as well as clinical features such as ulceration are important to document. (from AJCC 8th Ed.) 